\title{
THE INFLUENCE OF EATING HABITS OF MINAHASAN DISHES ON THE OCCURENCE OF CORONARY HEART DISEASE
}

\author{
Grace D. Kandou
}

Post Graduate Department of Public Health University of Sam Ratulangi Manado Department of Public Health Faculty of Medicine University of Sam Ratulangi Manado Email: gracekandou@yahoo.com

\begin{abstract}
Abstrak: Penyakit jantung koroner (PJK) merupakan masalah kesehatan jantung baik di dunia maupun di Indonesia termasuk Propinsi Sulawesi Utara, dan menempati urutan pertama sebagai penyebab kematian. Penyebab terjadinya PJK multifaktorial; salah satunya adalah kebiasaan makan yang dipengaruhi oleh faktor budaya, adat istiadat, agama dan kepercayaan. Penelitian ini dilakukan untuk mengetahui pengaruh kebiasaan makan makanan etnik Minahasa terhadap kejadian PJK. Metode case control dengan 128 kasus dan 128 kontrol yang diambil dari RSU Prof. Dr. R.D. Kandou. Dilakukan pengumpulan data frekuensi makan dengan menggunakan Food Frequency Quationnaire (FFQ) untuk melihat hubungan kebiasaan makan dengan PJK. Umumnya makanan etnik Minahasa mengandung asam lemak jenuh $0,01-10,46 \%$ per 100 gramnya. Seseorang yang mengomsumsi jenis makanan berisiko PJK seperti babi putar dengan frekuensi makan $\geq 2$ kali/bulan mempunyai kemungkinan terkena PJK 4,43 kali lebih besar dibanding dengan yang mengonsumsi $\leq 1 \mathrm{kali} /$ bulan, setelah dikontrol oleh babi hutan (OR=4,3 95\% CI:1,66-11,05), kotey/sa'ut (OR=7,15 95\%CI: 1,7030,08), merokok (OR=2,76 95\% CI: 1,36-5,61), usia ( $\mathrm{OR}=1,96$ 95\%CI: $1,36-2,83)$, jenis kelamin (OR=2,86 95\% CI: 1,41-5,78), dan hipertensi (OR=5,86 95\%CI: 2,94-11,66). Berdasarkan 41 jenis makanan yang dikomposit, seseorang yang mempunyai kebiasaan makan makanan etnik Minahasa dengan frekuensi sering (total skor $\geq$ nilai mean) mempunyai kemungkinan 5,4 kali lebih besar untuk terkena PJK dibanding dengan yang mempunyai kebiasaan makan jarang (total skor $\leq$ nilai mean), setelah dikontrol oleh faktor jenis kelamin, riwayat PJK dalam keluarga, dan diabetes.
\end{abstract}

Kata kunci: kebiasaan makan, makanan Minahasa, asam lemak jenuh, penyakit jantung koroner.

\begin{abstract}
Coronary Heart Disease (CHD) is the leading cause of disability and mortality in Indonesia and North Sulawesi as well as the rest of the world. There are many factors that contribute to the development of CHD. Eating habits are believed to be risk factors and are influenced by culture and religion. This research explores the influence of eating habits of the Minahasans, particularly of the dishes that contain high level of fats contributing to the development of CHD. The methodology of this research involved case controls. The respondents were taken from Prof. Dr. R.D. Kandou General Hospital in Manado, North Sulawesi. The samples were divided into two groups consisting of 128 cases of CHD and 128 cases without CHD for control. Eating frequencies were obtained through Food Frequency Questionnaires (FFQ). The purpose of using these analyses was to obtain the actual effects of the eating habits involving a variety of Minahasan dishes which were believed to have had some contribution to the risks of CHD. Those who ate whole roasted pigs more than twice a month were 4.43 times more susceptible to develop CHD compared to those who ate whole roasted pigs less than once a month, after being controlled by the eating of wild boar ( $\mathrm{OR}=4.3$ 95\% CI: 1.66-11.05), banana heart and stem (OR=7.15 95\% CI: 1.70-30.08), smoking $(\mathrm{OR}=2.76$ 95\% CI: $1.36-5.61)$, age $(\mathrm{OR}=1.96$ 95\% CI: 1.36-2.83), gender $(\mathrm{OR}=2.8695 \% \mathrm{CI}$ : 1.41-5.78), and hypertension (OR=5.86 95\% CI: 2.94-11.66). Based on the consumption of
\end{abstract}


41 kinds of Minahasan dishes, those who frequently ate these on a daily bases had a 5.4 higher probability of developing CHD with an eating habit score of $\geq$ mean value, compared to those who ate less frequently with an eating habit score of $\leq$ mean value, after being controlled by gender, family history of CHD, and diabetes mellitus.

Keywords: eating habit, Minahasan foods, saturated fatty acid, coronary heart disease.

Cardiovascular disease is still a hot topic in public health issues. It killed over 180,000 people in the United Kingdom and 500,000 people in the United States every year. ${ }^{1-3}$ Coronary Heart Disease (CHD) is an increasing cause of death in Indonesia with an increase from $11^{\text {th }}$ (Survei Kesehatan Rumah Tangga/SKRT 1972) to $3^{\text {rd }}$ (SKRT 1986) and becoming the main cause of deaths (SKRT 1992, 1995, and SKRT 2001, SKRT 2005). ${ }^{4}$ Moreover, North Sulawesi, as one of the thirty provinces in Indonesia, has the highest number of deaths caused by cardiovascular diseases. ${ }^{5,6}$ According to reports from Prof. Dr. R.D. Kandou General Hospital in Manado, the main reference hospital in North Sulawesi Province, cardiovascular disease was the main cause of deaths. ${ }^{7}$

CHD is a degenerative disease that is affected by atherosclerosis manifestated in coronary arteries, and other risk factors. There are risk factors that can be controlled or modified, such as hypertension, dyslipidemia, smoking, diabetes mellitus, obesity, stress, and physical inactivity. Besides that, there are also risk factors that can not be modified such as: age, genetics, gender, and race. ${ }^{8,9} \mathrm{CHD}$ risk was 2.5 times higher in people with family histories of CHD or sudden deaths before age 50 compared to people without these histories. ${ }^{10-12}$ Hypertension is closely related to $\mathrm{CHD}$, because hypertension increases the risk of CHD six times higher than normotension. ${ }^{13}$ Several studies showed that diabetes mellitus patients have greater risks (two to three times) to develop CHD compared to normal people. North Sulawesi has the highest prevalence of diabetes mellitus in Indonesia. ${ }^{5}$

Based on the national census year 2003, about $26 \%$ of Indonesians consumed vegetables less than seven times a week.
Around 86\% Indonesians (age $\geq 10$ ) consumed fruit less than seven times a week; only $2 \%$ consumed fruit $\geq 14$ times a week. $^{14}$

Hatma's research (2001) on four ethnic groups (Minangkabau, Javanese, Sundanese, and Bugis) in Indonesia found that saturated fatty acid was $21 \%$ of total energy consumption. ${ }^{15}$ Meanwhile, the American Heart Association (AHA) advised that saturated fatty acid consumption should be $<10 \%$ of total energy intake. It means that the saturated fatty acid consumption of Indonesians was high. ${ }^{10,15-18}$

Eating habits are influenced by sociocultural factors, customs, religions, and beliefs, and these habits identify how individuals or communities satisfy their nourishment needs. ${ }^{6}$

Indonesia has over 500 ethnic groups with various life styles; one of them is the Minahasans with a majority living in the North Sulawesi province where they comprise the largest ethnic group. ${ }^{19,20}$

The Minahasans usually celebrate parties with banquets, mostly consisting of Minahasan dishes derived from animal fat (mostly pork). The Minahasans eat pork as frequently as other Indonesian people eat beef. ${ }^{20}$

The objective of this research was to find out the influences of Minahasan consumption of dishes enriched by saturated fatty acids on CHD, including observations such as sedentary life style, smoking, alcohol consumption, as well as age, sex, family history, and associated diseases (hypertension, obesity, and diabetes mellitus).

\section{METHODS}

This research was carried out in the Prof. Dr. R.D. Kandou General Hospital, 
and was designed for non-randomized case control. Studies were made of new inpatients and outpatients, based on the hospital medical records. All of them had electrocardiography (ECG) examinations and were diagnosed by cardiologists as first time CHD patients (according to AHA guidelines/PERKI guidelines 2004). As control group, we took inpatients and outpatients with no CHD history, but who had had ECG examinations, and had been diagnosed by cardiologists as non CHD patients. $^{21}$

This research was preceded by a survey. Its objective was to find out the eating habits of the Minahasans living in North Sulawesi, especially those who consumed certain dishes that were high in saturated fatty acids. Observations were made of those dishes that were usual eaten by the Minahasans, daily or occasionally, e.g. in parties.

Furthermore, samples of food from party dishes and daily dishes were analyzed for their saturated fatty acid contents. The result was a new finding that could be included in the list of foods in Indonesia. Saturated fatty acid examinations of 41 dishes usually consumed by Minahasans were performed with gas chromatography by the Food \& Nutrient Laboratory in the Nutrient Research \& Development Center of the Health Department of the Republic of Indonesia in Bogor.

The research population was all the patients that came to Prof Dr R.D.Kandou General Hospital. Research samples were patients treated in the Cardiology Department of the hospital (based on inclusion and exclusion criteria). The control group patients were those not diagnosed as CHD patients and were treated in other sections. Before carrying out this research, all clearances were received from the Ethical Clearance Team of the Public Health Faculty, University of Indonesia, and from the Medical Committee of Prof.Dr RD Kandou General Hospital.

Sample size was calculated based on minimum sample formulation of 1:1 nonrandomized case and control; the result was $\mathrm{n}=128$ cases and $\mathrm{n}=128$ controls with a total sample number 256. Dietary assessment was held through Food Frequency Questionnaires (FFQ) concerning daily, weekly, monthly, and yearly eating habits. Data was processed by using the SPSS version 11(licensed), STATA 8 (licensed), and Windows Vista Basic Premium Microsoft Excel program.

Eating habit data received from FFQ were categorized in three columns of frequency: never, seldom, and often. The Receiver Operation Curve (ROC) analysis was executed to determine the cut off point for eating frequencies. The eating frequencies of subjects were obtained for all 41 kinds of Minahasan dishes. Univariate analysis for each research variable and bivariate analysis revealed 25 dishes that were related to the occurrence of CHD. For logistic regression we used five dishes that had the highest OR values, followed by a validiting interaction test for confounding variables. The results showed the effect of the kinds of high-risk dishes on the occurrence of CHD after controlling certain other factors (sedentary habits, smoking, alcohol consumption, age, sex, family history, hypertension, obesity, and diabetes mellitus). Then we analyzed combinations of several high-risk dishes.

The observations of eating habits were based on eating frequency considering the saturated fatty acids in the 41 dishes. Data was obtained from eating habits graded as 'seldom' and 'frequent' based on the cut-off point of the mean value because there was a normal distribution of data through the Kolmogorov-Smirnov test. Then bivariate analysis was held to see the relationship between each variable with the occurrence of CHD. Subsequently a multivariate analysis of logistic regression was carried out through the arrangement of the interaction analysis and confounding variables. Then we obtained the actual effects on the occurrence of CHD due to eating habits from frequently consumed dishes containing saturated fatty acids, compared with dishes of this type not regularly eaten. 


\section{RESULT}

\section{Case characteristics and controls}

Daily physical activity (in this research: sedentary life style) of the respondents was categorized by: lack of movement or adequate movement. We found that almost all of the case group $(86.75 \%)$ showed a lack of movement in their daily activities, while in the control group was $43.75 \%$

Smoking habits were seen in $55.47 \%$ of the case group, while in the control group it was only $22.66 \%$.

Alcohol consumption was identified in one-third $(32.81 \%)$ of the case group. There were several kinds of alcohol drinks: cap tikus (Minahasan drink made from distillation of palm sugar), beer, and various kinds of local wines.

Individual characteristics: $40.63 \%$ of the subjects in the case group were 55-64 years old, while in the control group was $37.5 \% ; 40.63 \%$ of the subjects in the case group were $\geq 65$ years old, while the figure was $24.22 \%$ in the control group. Thus, most of the subjects of the case group were older than those in the control group.

We found $61.72 \%$ were males in the case group, while only $28.91 \%$ in the control group were males.

Almost half (41.44\%) of the case group had CHD family histories, while that was true of only $24.22 \%$ in the control group.

Two-thirds (67.19\%) of the case group had medical records indicating hypertension as opposed to the control group with only $35.94 \%$.

Obesity or overweight was found in $62.5 \%$ of the case group, while only $37.5 \%$ in the control group.

Diabetes mellitus was found in $75 \%$ of the case group, in contrast to the control group which recorded $47.66 \%$ of families with histories of diabetes.

\section{Descriptions about saturated fatty acids in Minahasan dishes}

The saturated fatty acid contents in 41 Minahasan dishes were around 0.01$10.46 \%$ per 100 grams. One of the dishes, tina' $i$ (pork innards), had the highest fat content, as much as $10.46 \%$ per 100 grams of this dish. Dishes such as tinutuan (Manado vegetable porridge) had the lowest fat content, $0.01 \%$ per 100 grams.

Minahasan dishes that had high concentrations of saturated fatty acids (3.93$10.46 \%$ per 100 grams) were tina' $i$, ayam santan (chicken cooked with coconut milk), babi tore (crispy pork), roasted pork, supbrenebon babi (pork soup mixed with kidney beans), babi putar (whole roasted pig), babi garo rica (pork mixed with chilies), tinorangsak (pork and blood cooked in bamboo), pangi babi (pork mixed with pangi leaves), paniki (bat), babi asam manis (sweet and sour pork), soya bean pork, $R W$ (dog meat), babi hutan (wild boar), babi leylem (pork mixed with leylem leaves) and sup kuah asam babi (pork soup). On the other hand, dishes with low saturated fatty acids $(0.01-3.92 \%$ per 100 grams) are tinutuan, sayur pait (papaya leaves), kotey/sa'ut babi (banana flowers and trunks mixed with pork), ikan cakalang goreng (fried tuna fish), ikan laut wokublanga (fish cooked with various spices), ikan mujair bakar (roasted fresh water fish), ikan mujair goreng (fried fresh water fish), ikan cakalang fufu saus (smoked tuna fish), ikan mas bakar rica (roasted goldfish mixed with chili), ikan mas wokublanga (goldfish cooked with special spices), fried goldfish, kangkung tumis (sauteed water spinach), tikus (forest opossum), and sayur rica rodo (green bean mixed with corn and egg plant).

Almost all the dishes were made with pork. Minahasan dishes are usually quite spicy because they use a lot of chili (Capsicum fretescens/cayenne). Chili has a positive impact on the heart due to its important effects: anti-oxidant, anticoa-gulant, and antifibrinolytic. But the uniqueness of Minahasan dishes is that they consist of a variety of animal meats that are not usually found in other ethnic groups, such as bats, dogs, and forest opossum; as well as vegetables from banana trunks and flowers. Dishes made with opossum are also eaten in Zimbabwe. ${ }^{22-24}$ 
Besides saturated fatty acids, Minahasan dishes usually contain ginger and garlic. It is already known that ginger, especially red ginger (Zingiber officinale var rubrum) acts as an antioxidant that helps to neutralize the destructive effects of free radicals in the human body. Ginger stimulates the releasing of adrenalin and enlarges veins so that blood can more easily flow and help the work of heart in pumping blood. Gingerol in ginger is an anticoagulant that prevents blood agglutination, thus preventing the stepped up of vein as the main cause of heart attacks and strokes. ${ }^{25,26}$ The merit of garlic is that it decreases and stabilizes blood pressure, helps in decreasing the concentration of blood cholesterol, helps prevent blood coagulation, is a detoxifier and an antioxidant, and also has antibacterial effects. ${ }^{27}$

\section{The relationship of Minahasan foods to incidences of CHD}

From 41 Minahasan dishes analyzed, 25 dishes are related to the occurrence of CHD, meanwhile 16 other dishes had opposite effects. The OR values were around 12.212.02. Dishes such as kotey/sa'ut babi had the highest OR values, that is 12.21 (95\% CI: 3.61-41.24). Furthermore, the 25 Minahasan dishes that potentially influenced the occurrence of CHD were: tinorangsak, babi putar, babi hutan, babi leylem, babi garo rica, babi kecap, babi asam manis, roasted pork, babi tore, posana (liver, fat, and pork), kotey/sa'ut babi, sate babi, loba, tina'i, sayur pait babi, sup brenebon babi, sup babi kuah asam, sayur kangkung tumis babi, RW, paniki, tikus, ikan mas wok-ublanga, fried goldfish, ikan mas bakar rica, and ayam santan (Table 1 ).

The five dishes according the previous biivariate analysis that had the highest odd ratios were: sa'ut babi/kotey, paniki, loba, babi hutan, and babi putar. On the other hand, after carrying out a multivariate analysis of these five dishes, there remained three (babi putar, babi hutan and kotey /sa'ut babi) requiring further analyses. Through logistic regression, with other controlling factors, the end model showed the highest-risk dishes for CHD (Table 2).

People who consumed babi putar more than twice per month had a higher probability (4.43 times, 95\% CI: 1.55-12.65) of suffering from CHD compared to those who consumed the same dish less than once per month, in conjunction with other factors such as babi hutan, kotey/sa'ut, smoking, age, sex, and hypertension.

We analyzed high-risk dishes such as babi putar in combination with several other dishes that contain rica (bird's eye chillis), often consumed by Minahasans, and dishes that are rich in fibers such as papaya leaves. The result showed that the risk of CHD from eating babi putar combined with the dishes mentioned above has declined compared with that of babi putar alone. For example, the combination of babi putar with ikan mas bakar rica and/or babi garo rica in the multivariate analysis showed a decline in the OR value.

People that consumed babi putar combined with ikan mas bakar rica had a 3.47 times higher probability $(\mathrm{OR}=3.4795 \% \mathrm{CI}$ : 1.98-6.08) in getting CHD if the eating frequency $\geq 2 \mathrm{x} /$ month compared to those who consumed the same dishes $\leq 1 \mathrm{x} /$ month, in addition to being controlled by certain factors such as sex, hypertension, obesity, and diabetes mellitus.

People that consumed babi putar combined with babi garo rica had a 2.87 times higher risk $(\mathrm{OR}=2.8795 \% \mathrm{CI}: 1.77-4.67)$ of getting $\mathrm{CHD}$ if the eating frequency $>1$ $2 \mathrm{x} / \mathrm{month}$, compared to those who consumed the same dishes $<1 \mathrm{x} /$ month, with controlling factors such as age, hypertension, obesity, and diabetes mellitus. We assumed that these OR alterations were due to the positive effects (antioxidant, anti-coagulant, and antifibrinolytic) of rica on the heart.

The combination of babi putar with sayur pait also showed a decrease of OR. People who consume babi putar with sayur pait $\geq 2 \mathrm{x} /$ month have a 3.25 times higher probability of getting CHD compared to those who consume the same dishes $\leq$ $1 \mathrm{x} /$ month, in addition to being controlled by age and hypertension. 
174 Jurnal Biomedik, Volume 2, Nomor 3, November 2010, hlm. 169-178

Table 1. The relationship between 25 potential dishes in the occurrence of CHD

\begin{tabular}{|c|c|c|c|c|c|c|c|c|c|c|}
\hline \multirow{2}{*}{ No } & \multirow{2}{*}{ Variable } & \multicolumn{2}{|c|}{ Case } & \multicolumn{2}{|c|}{ Control } & \multirow{2}{*}{$\begin{array}{c}\text { Value } \\
\mathrm{p}\end{array}$} & \multirow{2}{*}{ OR } & \multirow{2}{*}{\multicolumn{3}{|c|}{$\begin{array}{c}\text { [95\% Conf. } \\
\text { Interval] }\end{array}$}} \\
\hline & & $\mathbf{N}$ & $\%$ & $\mathbf{n}$ & $\%$ & & & & & \\
\hline \multirow[t]{3}{*}{1} & Sa'ut babi/kotey & & & & & & & & & \\
\hline & Frequency $\geq 2 \mathrm{x} /$ month & 29 & 23 & 3 & 2 & 0.00 & 12.21 & 3.61 & - & 41.24 \\
\hline & Frequency $\leq 1 \mathrm{x} /$ month & 99 & 77 & 125 & 98 & & Ref & & & \\
\hline \multirow[t]{3}{*}{2} & Paniki & & & & & & & & & \\
\hline & Frequency $\geq 2 \mathrm{x} /$ month & 22 & 17 & 4 & 3 & 0.00 & 6.43 & 2.15 & - & 19.26 \\
\hline & Frequency $\leq 1 \mathrm{x} /$ month & 106 & 83 & 124 & 97 & & Ref & & & \\
\hline \multirow[t]{3}{*}{3} & Loba & & & & & & & & & \\
\hline & Frequency $\geq 2 \mathrm{x} /$ month & 28 & 22 & 6 & 5 & 0.00 & 5.69 & 2.27 & - & 14.29 \\
\hline & Frequency $\leq 1 \mathrm{x} /$ month & 100 & 78 & 122 & 95 & & Ref & & & \\
\hline \multirow[t]{3}{*}{4} & Babi hutan & & & & & & & & & \\
\hline & Frequency $\geq 2 \mathrm{x} /$ month & 42 & 33 & 11 & 9 & 0.00 & 5.20 & 2.53 & - & 10.67 \\
\hline & Frequency $\leq 1 \mathrm{x} /$ month & 86 & 67 & 117 & 91 & & Ref & & & \\
\hline \multirow[t]{3}{*}{5} & Babi putar & & & & & & & & & \\
\hline & Frequency $\geq 2 \mathrm{x} /$ month & 39 & 30 & 10 & 8 & 0.00 & 5.17 & 2.45 & - & 10.92 \\
\hline & Frequency $\leq 1 \mathrm{x} /$ month & 89 & 70 & 118 & 92 & & Ref & & & \\
\hline \multirow[t]{3}{*}{6} & Posana & & & & & & & & & \\
\hline & Frequency $\geq 2 \mathrm{x} /$ month & 19 & 15 & 5 & 4 & 0.01 & 4.29 & 1.55 & - & 11.87 \\
\hline & Frequency $\leq 1 \mathrm{x} /$ month & 109 & 85 & 123 & 96 & & Ref & & & \\
\hline \multirow[t]{3}{*}{7} & Babi asam manis & & & & & & & & & \\
\hline & Frequency $\geq 2 \mathrm{x} /$ month & 38 & 30 & 12 & 9 & 0.00 & 4.08 & 2.17 & - & 9.27 \\
\hline & Frequency $\leq 1 \mathrm{x} /$ month & 90 & 70 & 116 & 91 & & Ref & & & \\
\hline \multirow[t]{3}{*}{8} & Babi bakar & & & & & & & & & \\
\hline & Frequency $\geq 2 \mathrm{x} /$ month & 42 & 33 & 14 & 11 & 0.00 & 3.98 & 2.04 & - & 7.74 \\
\hline & Frequency $\leq 1 \mathrm{x} /$ month & 86 & 67 & 114 & 89 & & Ref & & & \\
\hline \multirow[t]{3}{*}{9} & Babi leylem & & & & & & & & & \\
\hline & Frequency $\geq 2 \mathrm{x} /$ month & 47 & 37 & 17 & 13 & 0.00 & 3.79 & 2.15 & - & 7.67 \\
\hline & Frequency $\leq 1 \mathrm{x} /$ month & 81 & 63 & 111 & 87 & & Ref & & & \\
\hline \multirow[t]{3}{*}{10} & Sate babi & & & & & & & & & \\
\hline & Frequency $\geq 2 \mathrm{x} /$ month & 106 & 83 & 76 & 59 & 0.00 & 3.30 & 1.88 & - & 5.88 \\
\hline & Frequency $\leq 1 \mathrm{x} /$ month & 22 & 17 & 52 & 41 & & Ref & & & \\
\hline \multirow[t]{3}{*}{11} & Sup babi kuah asam & & & & & & & & & \\
\hline & Frequency $\geq 2 \mathrm{x} /$ month & 42 & 33 & 17 & 13 & 0.00 & 3.19 & 1.64 & - & 5.78 \\
\hline & Frequency $\leq 1 \mathrm{x} /$ month & 86 & 67 & 111 & 87 & & Ref & & & \\
\hline \multirow[t]{3}{*}{12} & Babi tore & & & & & & & & & \\
\hline & Frequency $\geq 2 \mathrm{x} /$ month & 32 & 25 & 14 & 11 & 0.00 & 3.03 & 1.37 & - & 5.38 \\
\hline & Frequency $\leq 1 \mathrm{x} /$ month & 86 & 67 & 114 & 89 & & Ref & & & \\
\hline \multirow[t]{3}{*}{13} & Tina'i & & & & & & & & & \\
\hline & Frequency $\geq 2 \mathrm{x} /$ month & 19 & 15 & 7 & 5 & 0.03 & 3.01 & 1.14 & - & 7.03 \\
\hline & Frequency $\leq 1 \mathrm{x} /$ month & 109 & 85 & 121 & 95 & & Ref & & & \\
\hline 14 & Ikan mas wokublanga & & & & & & & & & \\
\hline & Frequency $\geq 2 \mathrm{x} /$ month & 48 & 38 & 23 & 18 & 0.00 & 2.74 & 1.54 & - & 4.87 \\
\hline & Frequency $\leq 1 \mathrm{x} /$ month & 80 & 63 & 105 & 82 & & Ref & & & \\
\hline 15 & Tikus & & & & & & & & & \\
\hline & Frequency $\geq 2 \mathrm{x} /$ month & 23 & 18 & 10 & 8 & 0.02 & 2.59 & 1.18 & - & 5.68 \\
\hline & Frequency $\leq 1 \mathrm{x} /$ month & 105 & 82 & 118 & 92 & & Ref & & & \\
\hline
\end{tabular}




\begin{tabular}{|c|c|c|c|c|c|c|c|c|c|c|}
\hline \multirow{2}{*}{ No } & \multirow{2}{*}{ Variable } & \multicolumn{2}{|c|}{ Case } & \multicolumn{2}{|c|}{ Control } & \multirow{2}{*}{$\begin{array}{c}\text { Value } \\
\mathrm{p}\end{array}$} & \multirow{2}{*}{ OR } & \multirow{2}{*}{\multicolumn{3}{|c|}{$\begin{array}{c}\text { [95\% Conf. } \\
\text { Interval] }\end{array}$}} \\
\hline & & $\mathbf{N}$ & $\%$ & $\mathbf{n}$ & $\%$ & & & & & \\
\hline \multirow{3}{*}{16} & RW & & & & & & & & & \\
\hline & Frequency $\geq 2 \mathrm{x} /$ month & 27 & 21 & 12 & 9 & 0.01 & 2.58 & 1.24 & - & 5.36 \\
\hline & Frequency $\leq 1 \mathrm{x} /$ month & 101 & 79 & 116 & 91 & & Ref & & & \\
\hline \multirow[t]{3}{*}{17} & Fried goldfish & & & & & & & & & \\
\hline & Frequency $\geq 2 \mathrm{x} /$ month & 36 & 28 & 17 & 13 & 0.00 & 2.56 & 1.43 & - & 5.25 \\
\hline & Frequency $\leq 1 \mathrm{x} /$ month & 92 & 72 & 111 & 87 & & Ref & & & \\
\hline \multirow[t]{3}{*}{18} & Babi garo rica & & & & & & & & & \\
\hline & Frequency $\geq 2 \mathrm{x} /$ month & 103 & 80 & 80 & 63 & 0.00 & 2.47 & 1.45 & - & 4.49 \\
\hline & Frequency $\leq 1 \mathrm{x} /$ month & 25 & 20 & 48 & 38 & & Ref & & & \\
\hline \multirow[t]{3}{*}{19} & Ikan mas bakar rica & & & & & & & & & \\
\hline & Frequency $\geq 2 \mathrm{x} /$ month & 32 & 25 & 16 & 13 & 0.01 & 2.33 & 1.28 & - & 4.91 \\
\hline & Frequency $\leq 1 \mathrm{x} /$ month & 96 & 75 & 112 & 88 & & Ref & & & \\
\hline \multirow[t]{3}{*}{20} & Tinorangsak & & & & & & & & & \\
\hline & Frequency $\geq 2 \mathrm{x} /$ month & 64 & 50 & 40 & 31 & 0.00 & 2.20 & 1.32 & - & 3.66 \\
\hline & Frequency $\leq 1 \mathrm{x} /$ month & 64 & 50 & 88 & 69 & & Ref & & & \\
\hline \multirow[t]{3}{*}{21} & Sup brenebon babi & & & & & & & & & \\
\hline & Frequency $\geq 2 \mathrm{x} /$ month & 65 & 51 & 42 & 33 & 0.00 & 2.11 & 1.27 & - & 3.50 \\
\hline & Frequency $\leq 1 \mathrm{x} /$ month & 63 & 49 & 86 & 67 & & Ref & & & \\
\hline \multirow[t]{3}{*}{22} & Sayur pait ba' & & & & & & & & & \\
\hline & Frequency $\geq 2 \mathrm{x} /$ month & 95 & 74 & 74 & 58 & 0.00 & 2.10 & 1.28 & - & 3.68 \\
\hline & Frequency $\leq 1 \mathrm{x} /$ month & 33 & 26 & 54 & 42 & & Ref & & & \\
\hline \multirow[t]{3}{*}{23} & Ayam santan & & & & & & & & & \\
\hline & Frequency $\geq 2 \mathrm{x} /$ month & 35 & 27 & 20 & 16 & 0.01 & 2.03 & 1.22 & - & 4.33 \\
\hline & Frequency $\leq 1 \mathrm{x} /$ month & 93 & 73 & 108 & 84 & & Ref & & & \\
\hline \multirow[t]{3}{*}{24} & Babi kecap & & & & & & & & & \\
\hline & Frequency $\geq 2 \mathrm{x} /$ month & 82 & 64 & 60 & 47 & 0.00 & 2.02 & 1.28 & - & 3.50 \\
\hline & Frequency $\leq 1 \mathrm{x} /$ month & 46 & 36 & 68 & 53 & & Ref & & & \\
\hline \multirow[t]{3}{*}{25} & Sayur kangkung tumis & & & & & & & & & \\
\hline & Frequency $\geq 2 \mathrm{x} /$ month & 85 & 66 & 66 & 52 & 0.02 & 1.86 & 1.12 & & 3.08 \\
\hline & Frequency $\leq 1 \mathrm{x} /$ month & 43 & 34 & 62 & 48 & & Ref & & & \\
\hline
\end{tabular}

Information: The bold words are dishes that have the highest OR values processed through multivariate analysis.

Table 2. The end model of multivariate analysis through the logistic regression shows the main variables (dishes) that are high-risk to CHD occurrence

\begin{tabular}{lccccccc}
\hline \multicolumn{1}{c}{ Variables } & Odd Ratio & Std. Err. & $\mathrm{Z}$ & $\mathrm{P}>|\mathrm{z}|$ & \multicolumn{2}{c}{$[95 \%$ Conf } & Interval] \\
\hline Babi putar & 4.43 & 2.37 & 2.78 & 0.00 & 1.55 & - & 12.65 \\
Kotey/ Sa'ut & 7.15 & 5.24 & 2.69 & 0.00 & 1.70 & - & 30.08 \\
Babi hutan & 4.29 & 2.07 & 3.02 & 0.00 & 1.66 & - & 11.05 \\
Smoking & 2.76 & 0.99 & 2.82 & 0.00 & 1.36 & - & 5.61 \\
Age & 1.96 & 0.36 & 3.62 & 0.00 & 1.36 & - & 2.83 \\
Sex & 2.86 & 1.02 & 2.93 & 0.00 & 1.41 & - & 5.78 \\
Hypertension & 5.86 & 2.05 & 5.03 & 0.00 & 2.94 & - & 11.66 \\
\hline
\end{tabular}


Table 3. The end model of logistic regression of eating habits and CHD occurrence after controlling other variables

\begin{tabular}{lcccccc}
\hline Variables & Odd Ratio & Std. Err. & Value $p$ & \multicolumn{2}{c}{ [95\% Conf.Interval] } \\
\hline Eating habits & 5.39 & 1.68 & 0.00 & 2.93 & - & 9.93 \\
Sex & 3.29 & 0.99 & 0.00 & 1.83 & - & 5.94 \\
CHD family history & 2.45 & 0.79 & 0.01 & 1.31 & - & 4.60 \\
Diabetes history & 3.75 & 1.19 & 0.00 & 2.01 & - & 6.99 \\
\hline
\end{tabular}

The relationship between eating habits of the Minahasans and the occurrence of CHD

In this research, eating habits were scored based on the frequency of saturated fatty acids consumed. The compositing of 41 dishes was carried out by multiplying eating frequencies (weighted) with the content of saturated fatty acid. The eating habit scores ranged from a minimum of 97 to a maximum of 922 , with a mean value of 413.53 which was the the cut-off point. Eating frequency was categorized as 'frequent' if an individual consumed the dishes $\geq 2$ $\mathrm{x} / \mathrm{month}$; and 'seldom' if an individual did that $\leq 1 \mathrm{x} /$ month. Then a bivariate analysis was carried out, followed by a multivariate analysis through an interaction test and a confounding process, to find the actual effect of eating habits after being controlled by certain other factors (Table 3 ). ${ }^{28}$

The actual effect of Minahasans' eating habits involving specific dishes that are rich in SFA on the occurrence of CHD is: people with 'frequent' eating habits have a 5.4 times higher risk of getting CHD (95\% CI: 2.93-9.93) compared to those with 'seldom' eating habits, which takes into account variables such as sex, CHD family history, and diabetes mellitus.

Minahasan's eating habits involve the frequent consumption of highly saturated fatty acids. Thus, there are high risks of occurrence of CHD. ${ }^{6,9}$

\section{CONCLUSION}

The saturated fatty acid content in Minahasan dishes was 0.01-10.46 \% per 100 grams. From the 41 Minahasan dishes, the ones that contained high saturated fatty acids (3.93-10.46 \%/100 grams) were tina' $i$, ayam santan, babi tore, babi bakar, brenebon babi, babi putar, babi garo rica, tinorangsak, pangi babi, paniki, babi asam manis, babi kecap, RW, babi hutan, babi leylem and sup kuah asam babi. Meanwhile, dishes that contained low saturated fatty acids (0.01-3.92 \% per 100 gram) were tinutuan, sayur pait, kotey/sa'ut, ikan cakalang goreng, ikan laut wokublanga, ikan mujair bakar, ikan mujair goreng, ikan cakalang fufu saus, ikan mas bakar rica, ikan mas wokublanga, ikan mas goreng, kangkung tumis, tikus and sayur rica rodo.

The high-risk dish accountable for a high occurrence of CHD is babi putar. People who consumed it $\geq 2 \mathrm{x} /$ month had a 4.43 times higher probability of getting CHD compared to those who consumed it $\leq$ $1 \mathrm{x} /$ month or never ate it, even taking into account the effects of age, sex, smoking, and hypertension, as well as the consumption of babi hutan and saut/kotey. Minahasans' eating habits with a 'frequent' score: $\geq$ mean value, and have a 5.4 times higher risk for getting coronary heart disease compared to those with a 'seldom' score: < mean value, taking into account certain factors such as sex, family CHD history, and diabetes mellitus.

\section{SUGGESTIONS}

- Special health promotion programs through the Health Promotion Section and the Non-transmittable Disease Treatment Section, with special focus on heart problems should be broadcast through various media such as the TV, 
newspapers, and magazines in North Sulawesi Province. This will familiarize society with the results of this research, so that especially Minahasan people, will be aware of the types of dishes that should be guarded against especially for those who are at risk of CHD.

- Moreover, the Health Department should target Minahasans, so that they will prudently decrease their frequency of eating, as well as their consumption of high-risk dishes such as babi putar, kotey/sa'ut, and babi hutan. The local government, public and religious leaders should take an active responsibility in supporting this effort to reduce the causes of CHD by increasing the intake of vegetables and fruits such as tinutuan and sayur pait.

- Efforts among institutions such as the Health Department, centers for public health (Puskesmas), hospitals, and related public facilities and organizations should be coordinated in each region. This will increase the awareness among citizens to choose healthy food that will not be a risk to CHD.

- Among the seafoods available in Minahasa that do not contribute to CHD is tuna fish.

\section{REFERENCES}

1. Mensah G, Brown D, Croft J, Greenlund K. Major coronary risk factors and deaths from coronary heart disease. Am J Prev Med 2005;29(581):68-74.

2. Setianto B. Tinggi badan dan gambaran lesi arteri koroner yang dilakukan arteriografi koroner di Rumah Sakit Jantung Harapan Kita. Jurnal Kardiologi Indonesia 2000;XXV (2):61-67.

3. World Health Organization. Global strategy on diet, physical activity, and health. Geneva, 2003 [cited 2008 June 27]. Available from: http://www.who.int/hpr/ NPH/docs/un_consultation.pdf

4. Profil Kesehatan Indonesia 2003, menuju Indonesia Sehat 2010. Jakarta: Departemen Kesehatan Republik Indonesia; 2005.

5. Darmojo B. Epidemiologi penyakit kardio- vaskular dan masalah gizi pada golongan usia lanjut di Indonesia. Risalah Widyakarya Pangan dan Gizi V. Jakarta: Lembaga Ilmu Pengetahuan Indonesia; 1992.

6. Van Eeuwijk, Keppel B. Budaya, kesehatan dan kemiskinan; Mencari model alternatif pelayanan kesehatan dalam pendekatan budaya di Sulawesi Utara. Media Kesehatan 2005;1(2):67-72.

7. RS Umum Pusat Malayang / RS Prof Dr R.D Kandou. Profil / Laporan RS Umum Prof dr R.D Kandou Tahun 2000-2004. Manado: RS Umum Prof dr R.D Kandou; 2005.

8. Braunwald E. Heart Disease (Seventh Edition). Philadelphia: W.B. Saunders Company, 2007.

9. Baraas F. Kardiologi molekuler, radikal bebas, disfungsi endotel, aterosklerosis, antioksidan, latihan fisik, dan rehabilitasi jantung. Jakarta: Yayasan Kardia Iqratama, 2006.

10. Gibson SR. Principles of Nutritional Assessment (Second Edition). Oxford: Oxford University Press, 2005.

11. Atriyanto P. Faktor-faktor risiko yang berhubungan dengan PJK pada pasien RSJ Harapan Kita Jakarta. Skripsi. Jakarta: FKM UI; 2000.

12. Tavani A, Augustin L, Bosetti C, Giordano L, Gallus S, Jenkins D, La Vecchia C. Influence of selected lifestyle factors on risk of acute myocardial infarction in subjects with familial predisposition for the disease. Prev Med. 2004;38(4):468-72.

13. Mussolini M, Madans J. The relation between fish consumption, death from all causes, and incidence of coronary heart disease: the NHANES I Epidemiologic Follow-up Study. J Clin Epidemiol. 2000; 53:237-244.

14. Dachroni. Perilaku Beresiko di Indonesia 2003. Jakarta: Pusat Promosi Kesehatan. Badan Litbangkes bekerjasama dengan Badan Pusat Statistik, Departemen Kesehatan RI, 2003.

15. Hatma RD. Nutrient intake patterns and their relations to lipid profiles in diverse ethnic populations. Disertasi. Jakarta: FKM UI; 2001.

16. Rustika. Asupan asam lemak jenuh dari makanan gorengan dan risikonya terhadap kadar lipid plasma pada kelompok usia dewasa. Disertasi. Jakarta: Program 
Epidemiologi Fakultas Kesehatan Masyarakat Universitas Indonesia; 2005.

17. Forouhi N, Naveed S. CVD Risk factors and ethnicity - A homogeneous relationship?. Atherosclerosis 2006; Supplements 711-19.

18. Ayu R. Pengaruh asupan asam lemak trans terhadap profil lipid darah. Disertasi. Jakarta: Program Epidemiologi Fakultas Kesehatan Masyarakat Universitas Indonesia; 2007.

19. Mamengko RE. Etnik Minahasa dalam akselerasi perubahan: Telaah historis, teologis, antropologis. Jakarta: Pustaka Sinar Harapan, 2002.

20. Weichart G. Minahasa identity: A culinary practice. Antropologi Indonesia 2004; 28(74):55-74.

21. Gordis L. Epidemiology (Third Edition). Philadelphia: Elsevier Saunders, 2004.

22. Jeany. Serba pedas dari dapur Tomohon. Boga, Republika, 17 Februari 2008.

23. PERSI P.D. Khasiat pisang. Obat tradisional. [ cited 2008 June 27]. Available from: http://www.pdpersi.co.id/?show= detailnews\&kode $=1039 \&$ tbl=alternatif
24. Merchant AT, Dehghan M, Chifamba J, Terera G, Yusuf S. Nutrient estimation from an FFQ Developed for a black Zimbabwean population. Nutr J. 2005;4:37.

25. Rungkat F. Jahe berpotensi mencegah infeksi virus. Departemen Ilmu dan Teknologi Pangan, Institut Pertanian Bogor. Kompas Cyber Media. 2008 [cited 2008 June 10]. Available from: http://www.depkes.go.id/index.php?optio $\mathrm{n}=$ articles\&task $=$ viewarticle $\&$ artid $=263$ \&Itemid=3

26. Departemen Pertanian. Khasiat Bumbu Dapur Membunuh Bakteri. [cited 2008 June 10]. Available from: http://www.indone sia.go.id/id/index.php?option=com_cont ent\&task=view\&id=701\&Itemid=699

27. Winarno Bondan. Khasiat bawang putih.[cited 2008 July 5]. Available from: http://www.sasak.net/modules/newbb/vie wtopic.php?topic_id $=2362 \&$ forum $=28$

28. Takashi H. The essential relationship between heart health and chilli peppers. [cited 2008 June 11]. Available from: http://www.lowerbloodpressurecheap.co $\mathrm{m} / \mathrm{feed}$. 